\title{
Ssciendo
}

Ethics \& Bioethics (in Central Europe), 2021, 11 (3-4), 117-125

DOI:10.2478/ebce-2021-0017

\section{Epistemic and ethical responsibility during the pandemic}

\begin{abstract}
Andrea Klimková ${ }^{1}$
Abstract

Intellectual (specialised) knowledge is omnipresent in human lives and decisions. We are constantly trying to make good and correct decisions. However, responsible decision-making is characterised by rather difficult epistemic conditions. It applies all the more during the pandemic when decisions require not only specialised knowledge in a number of disciplines, scientific consensus, and participants from different fields, but also responsibility and respect for moral principles in order to ensure that the human rights of all groups are observed. Pandemic measures are created by politicians, healthcare policy-makers, and epidemiologists. However, what is the role of ethics as a moral philosophy and experts in ethics? Experts in ethics and philosophy are carefully scrutinising political decisions. Levy and Savulescu (2020) have claimed that Ethicists and philosophers are not epistemically arrogant if they question policy responses. They played an important role in the creation of a reliable consensus. This study analyses epistemic and moral responsibility, their similarities, analogies, and differences. Are they interconnected? What is their relationship and how can they be filled with actual content during the pandemic?
\end{abstract}

Keywords: epistemic responsibility, moral responsibility, epistemic communities, knowledge during the pandemic

\section{Introductory notes and outline of the issue}

The urgent need to address the theoretical as well as practical aspects of human decision-making and actions in terms of ethics and morals has gained even more importance during the COVID19 pandemic. Ethicists and philosophers are not epistemically arrogant if they question policy responses (Levy \& Savulescu, 2020). They play an important role in the creation of a reliable consensus. During the pandemic, many experts in ethics and philosophy have focused on clinical medicine and public healthcare dilemmas (justice, fair access to resources and healthcare, patient care, obligation to provide healthcare, clinical demand, allocation of resources, human rights, ethical aspects of vaccination, etc.), and the attention paid to these issues is undoubtedly deserved. However, there are other ethical and moral questions related specifically to knowledge. Research and knowledge, whether they relate to diagnostics, treatment, prevention, transmission, containing the Coronavirus COVID-19 (SARS COV 2) as well as the social impact of the pandemic, are of key importance. Delays in preventive, diagnostic, or therapeutic interventions may lead to major damage and even casualties (the greatest burden a person or society can carry is the burden of death). All this creates enormous pressure on scientists and scientific communities, but also research as such. The processes are often expected to speed up, which may affect the quality of research, and has to do with epistemic and moral responsibility.

The main goal of this study is to reflect the moving limits of moral responsibility in research and knowledge during the pandemic, examine and analyse the basic attributes of epistemic responsibility held by scientists and experts in ethics, and last but not least, present the concept of epistemic responsibility proposed by Lorraine Code as one of the approaches to epistemic (intellectual) responsibility. The text analyses the basis and some consequences of Lorraine Code's approach, which can be seen as a model of epistemic responsibility tailored for times when the social dimension and social context need addressing.

\footnotetext{
${ }^{1}$ Matej Bel University in Banská Bystrica (Slovakia); andrea.klimkova@umb.sk; ORCID: 0000-0003-4596-2492
} 
Neil Levy and Julian Savulescu refer to an epistemic storm in their publication entitled Epistemic responsibility in the face of a pandemic (2020). ${ }^{2}$ The question is whether lay persons should rely solely on epidemiology in an epistemic situation, which resembles a storm. In other words, many questions remain unsolved while others still lack a scientific consensus. There is a discourse (conflict) between those who advocate far-reaching interventions and those who insist on waiting for more data. This discourse addresses epistemic obligations and responsibility (Levy \& Savulescu, 2020). Policy makers are also affected by this discourse and many of them choose to be rather careful about their decisions. ${ }^{3}$ However, many authors have pointed out that research cannot be stopped and the hypotheses cannot remain untested: the decisions cannot be delayed during the pandemic - right now, there is no time to wait. Decisionmaking takes place even during times of epistemic insecurity, during times referred to as an "epistemic storm" by Levy and Savulescu.

Human knowledge is fallible, which requires constant creation of opportunities for critical discussion to ensure that our (actual) beliefs are justified; it can also help us avoid errors and reveal possible gaps in our convictions and opinions. A single viewpoint cannot justify these convictions at a time when scientific hypotheses are tested under enormous pressure and sped up. There are many other questions related to science and research, which require consideration of the epistemic and moral responsibility held by scientists, epistemic communities, policy makers, but also experts in ethics and philosophy who assess and evaluate the decisions made by the former group during the pandemic, i.e. an emergency situation. The title of the paper clearly and explicitly states that the issues arising from the current pandemic period are related to knowledge and science (not only epidemiology) and research (not only biomedical) as well as policy makers' decisions. Epistemic or intellectual responsibility of scientists represents an important aspect of knowledge acquisition. The examples presented in the introduction (coping with the burden of the pandemic and the evaluation of its consequences in terms of life, death, and welfare) show that responsibility related to knowledge ${ }^{4}$, actual scientific knowledge as a product of reliable and strict testing, comprises both epistemic (intellectual) and moral responsibility of the scientists. I study and think epistemic and moral responsibility during a pandemic from an ethical point of view (not epistemology).

\section{The moving limits of responsibility}

Science is a critical activity. Science has neither reached a reliable consensus, nor answered all the difficult questions about our survival of the pandemic, which makes the questions of epistemic and moral responsibility even more relevant. A moral agent's (e.g., a scientist, an expert in ethics) knowledge and beliefs are considered epistemically responsible if they are justified, and irresponsible if they are unjustified. Cintora (2011) has further explained that if the agent believes in something they cannot justify with evidence, it is epistemically irresponsible. Popper (2012) has claimed that objective knowledge is closely related to the social aspect of the scientific method: scientific objectivity does not result from individual

\footnotetext{
2 The focus on the social dimension of knowledge and emphasis on the social context are not new, they can be traced back to J. S. Mill. There has been a return of discussions about the consensus theory of truth, scientific consensus, and also internalism vs. externalism in the philosophy of science. Most current (analytically oriented) epistemologists consider the intentions of the so-called tripartite definition of knowledge, according to which knowledge corresponds to a belief that is both true and substantiated (Démuth, 2009, pp. 19-21).

${ }^{3}$ The principle can be simplified as follows: if we have to decide between alternatives, we should always avoid the one that may cause serious harm (Clarke, 2005; Vladyková, 2015) or negative consequences.

${ }^{4}$ The term "knowledge" is used based on Démuth's analysis in the first chapter of his book entitled Poznanie, vedenie alebo interpretácia (2009). The author has defined knowledge as well as semantically related epistemic terms to distinguish them. A tripartite definition of knowledge calls for truthfulness, (correct) belief, and justification (Démuth, 2009).
} 
scientists' effort to be "objective". Scientific objectivity is not an individual matter, it is a social one and draws exclusively from criticism - scientists criticising one another (Popper, 1992). ${ }^{5}$ Tense discussions between scientists and politicians should inspire us to search for the "correct" interpretation. However, in terms of epistemic responsibility, the tested and verified hypotheses, hard facts (expert opinions, research, records), and justification influence clinical decisionmaking. This knowledge permeates the broader social and political environment. Knowledge in the form of concepts is (re)formulated in the social environment and interpreted by both media and political discourse. Scientific concepts represent the objective criteria and norms in terms of decision-making during this pandemic calling for responsibility as an objective value or causal relationship (responsibility for something). In the search for an objective viewpoint for evaluating decision-related responsibility, the fact that the healthcare system and its participants do not exist in a world of abstract rules or an imaginary vacuum outside of social discourse, political and social narratives, and expectations is sometimes forgotten.

The difficult task of searching for clear ethical criteria distinguishing good and bad decisions is in the hands of philosophers and experts in ethics. During the pandemic period, it is their obligation to evaluate the recommendations formulated by scientists as well as political decisions. To construct an ethical framework, it is necessary to realise that assigning responsibility is inevitably a political act. It is an act performed from a specific position, therefore it is inherently subjective.

In ethical reflection, moral responsibility as a form of social relationship carries a variety of semantic components: "the subject is responsible for its actions as well as the actions of others, i.e. it exceeds their objective responsibility" (Smreková \& Palovičová, 2009, p. 8). Max Weber (1965) has claimed that a responsible person accepts the burden of the unpredictable consequences resulting from their own actions. However, responsibility can be perceived from different viewpoints, for example, as the ability to provide a guarantee (the guarantor is held accountable). The act of assigning responsibility presupposes a clear formal and informal system of ethical rules providing a normative framework to determine whether any rules have been broken, which rules and who has broken them. Biomedical (and epidemiological) research as well as clinical practice follow the rules set out in international documents, national legislative frameworks, and professional codes. Despite this, the role of experts in philosophy and ethics remains difficult. Assigning responsibility for incorrect decisions is often a vague process. The impact of the aforementioned concepts on the formulation and interpretation of ethical criteria or norms in care provision during the pandemic will be illustrated using the recent decision made by a renowned Slovak expert in bioethics and member of the National Ethical Committee, Peter Sýkora. From 2005 to 2021, he was a member of the Ethical Committee at the Ministry of Health of the Slovak Republic. As of 1 March 2021, he resigned from the Committee because he believed the national vaccination strategy was unethical.

\section{Moral responsibility in the pandemic times and public health}

Knowledge is related to epistemic responsibility for information as well as the way it is obtained, i.e. whether it has been obtained from an authority in the field (epistemic authority). Decision-making is related to epistemic as well as moral responsibility for the decisions and actions. An authority in the field (epistemic authority) should have good education, significant achievements, good reputation in the scientific and epistemic communities, and a good position in a scientific or research institution. "Good" as a term can be defined as correct, appropriate, or acceptable when referring to a phenomenon or state. In ethics, this term can be used in two

\footnotetext{
${ }^{5}$ In the published work Kritický racionalizmus a metóda falzifikácie (2019), Miloš Taliga defends the opinion that Popper's critical rationalism deserves attention even today. As he states, it is precisely "that is why scientists engage in critical testing of theories" (Taliga, 2019, p. 27).
} 
ways: instrumental when referring to a function or attributive when referring to a person who can act in a good way (Tugendhat, 1993, pp. 55-56).

Philosophers usually recognize two necessary individual and sufficient conditions upon which a person is morally responsible for their actions. The first condition is freedom while the second one is an epistemic state referred to as knowing. The first condition refers to the degree of freedom or control moral participants have over their actions; the second condition refers to the epistemic or cognitive state of the moral participants, i.e. whether they can be held responsible for their actions and their consequences.

While the first condition prompts us to ask "was this person acting freely when she did A?", the second condition prompts us to ask "was this person aware of what she was doing (of its consequences, moral significance, etc.)?" (Stanford Encyclopedia of Philosophy, 2021).

Epistemic and moral responsibility applies not only to scientists and scholars, but also the politicians and policy makers who are currently under enormous pressure. On the one hand, this pressure is created by those scientists who call for necessary, legitimate pandemic measures (vaccination, face masks, limited movement, etc.). On the other hand, a part of the public protests (demonstrates) against these measures arguing that they violate their freedom and human rights. Politicians are even attacked by some experts (doctors, lawyers) who claim to protect autonomy and freedom, but mainly try to get more followers on social media. When their arguments are not supported by the scientific consensus, it can be evaluated as epistemically irresponsible.

When the emphasis is on the public good, decisions in the public interest as well as political ethics are called for, but it does not happen in a vacuum as the problems are real. Nevertheless, political decisions are often inconsistent, inconsequential, inflexible and deviate from the opinions of experts not only in epidemiology, but also ethics and philosophy. Can such decisions be labelled as morally irresponsible if they relate to responsibility for public health? If a politician faces an important decision during the pandemic and epistemic storm and has to decide between ethics \& scientific consensus vs. personal interest, what do they choose? Will they act in a morally responsible way or prefer their personal interest to please the public? Peter Singer refers to the choice between ethics and personal interest as "the ultimate choice" (Singer, 1997, p. 4). Singer perceives this decision as a choice between two ways of life: the first choice is determined by one's personal interest, while the other is guided by morals or certain balance between morals and personal interest (e. g. re-election). The principle of responsibility in politics has been justified and emphasized by a number of theoreticians (e.g. Weber, 1965; Jonas, 1984). ${ }^{6}$ The responsibility for survival or, in other words, future generations is a part of political responsibility. It bears three attributes: (1) totality - while a politician holds the office or power, they bear responsibility for the citizens' lives and public well-being; (2) continuity responsibility lasts while the person holds the office; (3) future - responsibility goes beyond the immediate presence and applies to future consequences as well (Jonas, 1984). Dagmar Smreková (2000) has explained that the principle of responsibility "is mainly spatial and represents the legal, allowed actions (everything which is not forbidden by the law is allowed). Its relevance increases when the rules of the game have not been specified a priori and the responsibility itself cannot be reduced exclusively to the evaluation of rule observation"

\footnotetext{
${ }^{6}$ In his lecture entitled Politics as a vocation (1990), the German sociologist Max Weber considers responsibility as an integral personality attribute along with passion and the ability to estimate. A politician's passion means their devotion to a cause, but "mere passion, however genuinely felt, is not enough. It does not make a politician, unless passion as devotion to a 'cause' also makes responsibility to this cause [...]" (Weber, 1965, p. 60).
} 
(Smreková, 2000, p. 631). It is the policy area that is characterized by the fact that the consequences of political decisions are not visible here and now, but go beyond the present.

The importance of measures at the point when the number of persons contracting the SARS$\mathrm{CoV} 2$ virus is rapidly rising again is easier to understand if we suppress the individual perspective and see ourselves as a part of society in terms of public health. As the term itself indicates, the ethics of social consequences evaluates the correctness of human thinking, decision-making, and actions based on the consequences, although such formulation is quite simplified. Nevertheless, the need to address the practical aspects of human decision-making, actions, and behaviour in terms of ethics and morals is a part of our everyday life (Gluchman, 1995), and in pandemic conditions, it grows. Evaluating the consequences of the decisions made by scientists and politicians (or secondarily, their main motives and intentions, which can result in negative social consequences) is a serious matter. The point is that not only those who contract the virus and suffer from serious symptoms are at risk. There are other patients whose treatment will be postponed due to the situation, potential collapse of the health care system due to the number of patients, loss of employment, isolation, rise of domestic violence, economic decline, and many other negative social consequences. Positive social consequences "help to satisfy the necessity of moral agent, social community or society as such" (Gluchman, 1994, p. 19) although they are not prioritised. Vasil Gluchman (2008, p. 77) has explained that "the core values of ethics of social consequences are: humanity, human dignity and moral right", they interact with the value of positive social consequences. During the pandemic, responsibility can be analysed in the context of knowledge, freedom, autonomy, or even the way it is ascribed. The moral responsibility held by politicians undoubtedly applies to making decisions related to humanity and human dignity (patients, seniors, Roma, homeless, incomplete families, the unemployed, or citizens in general). Ethics of social consequences shows that these values can be analysed in terms of consequentialist theories, they are not reserved for deontological ethics. In terms of methodology, the specific situation represents the starting point to identify the positive social consequences. According to the author of this concept, the situational approach is a feasible method because positive social consequences can be filled with different content, even ambivalent at first sight (Gluchman, 1996). To summarise, the consequences of a situation can be evaluated if all the facts, factors, and morally relevant circumstances are known. Ethics of social consequences avoids the principle of maximisation and utility; therefore, it can be categorised as non-utilitarian consequentialism.

As for specific decisions made by the politicians, mainly those related to compulsory face masks, lock-down, and vaccination are being challenged. Can the state legitimately require the citizens to comply? Freedom should be restricted as little as possible, but in this situation, it is necessary to consider not only the justification of the aforementioned decisions, but also their consequences. These decisions can be perceived as interfering with individual freedom and rights, but people are individual as well as social beings: we live in society. Social prosperity and well-being are determined by the (health) condition of society. During the current SARS$\mathrm{CoV}-2$ pandemic, the goals of society are to save lives, reduce the spread of the disease, prevent the healthcare system from collapsing, and minimise the social consequences of the pandemic. These goals are legitimate and so are the political decisions as far as they follow these goals and are epistemically and morally responsible. This paper does not focus on humanity, dignity, and moral rights (and their violation) from the viewpoint of ethics of social consequences. It examines whether ethics of social consequences can provide any evaluation criteria that could be useful in the evaluation of pandemic political decisions. Can it be used to evaluate whether a decision has been morally responsible (in terms of positive social consequences, humanity, human dignity, and moral rights) or not? As of today, there is no clear answer. These decisions are still being made and it is impossible to evaluate the consequences - there is no reliable scientific consensus on the relevant questions so far. However, I am inclined to justify that yes. 
We must evaluate every decision in politics in the light of its social consequences. As it was claimed in the introduction, experts in philosophy and ethics are not epistemically arrogant if they challenge political decisions. They play an important role in the creation of a reliable consensus.

Levy and Savulescu (2020) have stated that:

\begin{abstract}
there are many different approaches non-epidemiologists - decision-makers and experts in other fields alike - might take, the following three seem to be the most widely advocated: (i) Attempt to adjudicate the debate between the experts; (ii) Attempt to split the difference between experts; (iii) Attempt to identify which of the competing experts is more likely to be reliable. None of these options is very acceptable, but some are more irresponsible than others (Levy \& Savulescu, 2020).
\end{abstract}

\title{
Epistemic responsibility (Lorraine code)
}

The philosopher Lorraine Code seems to be right when she claims that a person cannot understand human actions if they are separated from life, history, contexts, and stories. Therefore, concepts such as knowledge, virtue, or integrity can only be understood if their complexity and different angles are taken into consideration. In her book entitled Epistemic responsibility (2020), Code has explained that having adequate knowledge about the world is not only a matter of survival, but also an obligation. If we are to take the right actions, we need to read the world correctly. Philosophers refers to this obligation to "know well" as "epistemic responsibility." Code (2020) has defined knowing as a creative process ruled by the imperatives of epistemic responsibility, i. e. good and correct knowledge is necessary for taking good and correct actions.

Before the model of epistemic responsibility proposed by Code is presented, it is necessary to point out that in terms of mainstream epistemology, this project is atypical. As explained at the beginning, the generally acceptable definition specifies knowledge as a true and justified belief. "Knowledge is a true claim or belief but it also comprises the ability to provide evidence about its own truthfulness" (Démuth, 2009, p. 22). Such definitions are in line with the classical analytical tradition as well as common language intuition related to epistemic terms - "only true propositions (statements) can be known, we must believe our knowledge, and our belief must be evidence-based. There has to be a reason why we have this belief, i. e. this belief itself has to be justified by a belief" (Szapuová, 2003, p. 267). However, the dominant approach to knowledge is often criticised due to its "high level of abstraction and idealisation as well as certain ignorance toward the actual conditions of knowledge" (Szapuová, 2003, p. 269) as well as the fact that certain models and standards of justification apply to ideal conditions and ideal cognitive participants.

Code's alternative to the mainstream line of thinking in epistemology and the traditional tripartite model is based on the idea that the actual conditions for knowing and justification are not only epistemic but also moral. Responsibility for knowing involves three assumptions: (1) knowledge and the effort to know are a part of human life and result from the interaction between cognitive participants, their communities, and the world; (2) there is no knowing without scientists and no knowledge without the context; (3) people have access to knowledge and shape its contents and structure (Code, 2020). Code suggests looking at human cognitive activity in another way and asking different questions. A different perspective allows for looking for the missing complement to foundationalist and coherentist theories. Code deals with good cognitive activity in a way the foundationalist or coherentist approaches do not (Code, 2020). Her intention is to show that some varieties of epistemic proceedings are better and more responsible than others. "Knowing well, being epistemically responsible, have implications for people's individual, social, and political lives" (Code, 2020, p. 41). 
She uses the example of Phillip Gosse, Sr. (Father and Son: A case study) to illustrate an epistemological crisis faced by a scientist, which arose due to his internal intellectual conflict involving two antagonistic beliefs. Gosse tried to harmonise his fundamentalist Christian belief with the knowledge he has gained as a marine zoologist structured by new biology and the theory of evolution (Darwin, Lyell, etc.). Code analysed his epistemic responsibility when he ultimately chose Creationism and the story of Genesis - this conflict prevented him from holding responsibility for his further work.

"A 'responsibilist' approach to epistemology, for which epistemic responsibility is a pivotal normative concept, says that the nature of the knower and of his/her environment and epistemic community are epistemologically relevant, for they act as enabling and/or constraining factors in the growth of knowledge, both for individuals and for communities" (Code, 2020, p. 57). Code has explained that the "integrity of your source is a crucial component in my decision about whether or not to accept what you say, or even whether to consider it seriously. My estimation of your reliability in relaying testimony is equally important." A person's actions can be evaluated by taking into account their character, moral integrity, and reliability. Their cognitive activity can also be evaluated: in the context of the epistemic reliability of science. Thus arises the question: who can we trust and why? The author suggests that if we apply the aforementioned to evaluate one's intellectual activity (knowing), we examine intellectual virtues and appeal to the social criteria of virtuous intellectual behaviour. In other words, an epistemological evaluation focuses not only on individual actions, but also acceptable social practice. Code has further claimed that epistemic responsibility "is a central virtue from which other virtues radiate. This is analogous to the way in which, for hedonists, happiness is the central good, for Kant, good will is the only good in itself, from which all other goods derive" (Code, 2020, p. 77).

Her approach focuses on the social context of knowing and knowledge, and the fact that they are anchored in a network of social relationships as well as cultural and historical meanings. Bruno Latour and Steve Woolgar have explained that although research itself takes place behind the closed laboratory door, human beings are a part of society - they are social, and their intellectual activity takes place in Lebenswelt anyway (Laboratory Life, 1979). Everything that will be perceived and accepted as a suitable method, strategy, procedure, or result is a product of social negotiation and communication. It might be useful to remind the reader that while social epistemology reflects the results of inquiry, it studies the social dimension of knowledge, "which involves not only the institutions creating knowledge, but also interpersonal experience and communication of the participants" (Szapuová, 2003, p. 271).

\section{Conclusion}

During the current pandemic, mainstream discourse (specialised and political) involves experts who advocate far-reaching interventions and restrictions versus those who insist that the decisions (on measures, lock-down, medication, child vaccination, etc.) must be postponed until there is sufficient evidence. This discourse addresses the epistemic and moral responsibility of scientists as well as politicians. Governments rely on science and selected experts; as there is no time to wait for more evidence, such policy can be considered epistemically and morally responsible. Epistemic responsibility is achieved by following the advice provided by experts (not only epidemiologists, but also other scientists and scholars e. g. in ethics). According to L. Code, a scientist's (thinker's) character determines whether we take their claims seriously. Therefore renowned, trustworthy scientists with good reputations are selected.

Ethicists and philosophers are not epistemically arrogant if they challenge political decisions. They play an important role in the creation of a reliable consensus in the time of epistemic storm as Levy \& Savulescu (2020) writes about. When decisions are a matter of survival and coping with a pandemic, they involve consequences in terms of life, death, and 
welfare, therefore it is our moral obligation to evaluate them. Epistemic and moral responsibility held by experts in ethics involves challenging political decisions. They carry the burden of responsibility; therefore they cannot stop evaluating and pointing out incorrect, unacceptable, and irresponsible decisions. An expert in bioethics Sýkora, analysed the Slovak vaccination strategy as well as data about infected people and casualties and claimed that "the record number of deaths is a consequence of incorrect strategy". Although he has admitted that it is too soon to evaluate the pandemic, he has criticised the Slovak vaccination strategy, claiming that "we have sacrificed the seniors" (Horák, 2021). It can be stated that during the initial period of vaccination (March - June 2021), the vaccination strategy could not be considered acceptable in terms of epistemic and moral responsibility in relation to seniors as the most vulnerable group.

\section{References}

CINTORA, A. (2011): Brief commentary on Michael Williams' criticism of Agrippan scepticism. In: Logic and Philosophy of Science, 9(1), pp. 539-554.

CLARKE, S. (2005): Future technologies, dystopic futures and the precautionary principle. In: Ethics and Information Technology, 7(3), pp. 121-126.

CODE, L. (2020): Epistemic responsibility. Albany: State University of New York Press.

DÉMUTH, A. (2009): Poznanie, vedenie alebo interpretácia? [Knowledge, guidance or interpretation?]. Pusté Úl'any: Schola Philosophica.

GLUCHMAN, V. (1994): Angažovanost', solidarita, zodpovednost' [Commitment, solidarity, responsibility]. Prešov: Universum.

GLUCHMAN, V. (1996): Etika sociálnych dôsledkov a jej kontexty [Ethics of social consequences and its contexts]. Prešov: PVT

GLUCHMAN, V. (2008): Etika a reflexie morálky [Ethics and reflection of morality]. Prešov: Filozofická fakulta Prešovskej univerzity

HORÁK, O. (2021): Táto krajina nie je pre starých. Interview s bioetikom P. Sýkorom. [This country is not for the old. Interview with bioethicist P. Sýkora]. In: DenníkN, April 26, 2021 [online] [Retrieved August 1, 2021] Available at: https://dennikn.sk/2359545/tato-krajina-nieje-pre-starych-minimalizovat-pocet-umrti-na-slovensku-nebol-ciel-vravi-bioetik-sykora-oockovacej-strategii/

JONAS, H. (1984): The Imperative of Responsibility: In Search of an Ethics for the Technological Age. Chicago: The University of Chicago Press.

LATOUR, B. \& WOOLGAR, S. (1979/1986): Laboratory life: The construction of scientific facts, 2nd ed. Princeton, NJ: Princeton University Press.

LEVY, N. \& SAVULESCU, J. (2020): Epistemic responsibility in the face of a pandemic. In: Journal of Law and the Biosciences, 7(1), [online] [Retrieved May 15, 2021] Available at: https://doi.org/10.1093/jlb/lsaa033

POPPER, K. R. (2012): The open society and its enemies. London \& New York: Routledge.

POPPER, K. R. (1992): In search of a better world: Lectures and essays from thirty years. London \& New York: Routledge.

SINGER, P. (1997): How are we to live? Ethics in an age of self-interest. Sydney: Random House.

SMREKOVÁ, D. (2000): K dvom významom pojmu zodpovednost' [Two meanings of the term responsibility]. In: Filozofia, 55(8), pp. 620-631.

SMREKOVÁ, D. \& PALOVIČOVÁ, Z. (2009): Dvojznačnost' etických pojmov [Ambiguity of ethical concepts]. Bratislava: Filozofický ústav SAV.

STANDFORD ENCYCLOPEDIA OF PHILOSOPHY (2021): The epistemic condition for moral responsibility [online] [Retrieved July 25, 2021] Available at: https://plato.stanford.edu/entries/moral-responsibility-epistemic/ 
SZAPUOVÁ, M. (2003): Otázky feministickej epistemológie v kontexte súčasných epistemologických iniciatív (naturalizovanej a sociálnej epistemológie) [Issues of feminist epistemology in the context of current epistemological initiatives (naturalized and social epistemology)]. In: Brněnské přednášky [Brno lectures]. Brno: Masarykova univerzita, pp. 267-284.

TALIGA, M. (2019): Kritický racionalizmus a metóda falzifikácie [Critical rationalism and the method of falsification]. Banská Bystrica: Signis.

TUGENDHAT, E. (1993): Vorlesungen über Ethik [Lectures on Ethics]. Frankfurt: Suhrkamp. VLADYKOVÁ, L. (2015): Úvod do filozofie ekológie [Introduction to the philosophy of ecology]. Košice: Univerzita Pavla Jozefa Šafárika v Košiciach.

WEBER, M. (1965): Politics as a vocation. Philadelphia, PA: Fortress Press. 